\title{
DETERMINAN REVIU LAPORAN KEUANGAN DAN IMPLIKASINYA TERHADAP KUALITAS LAPORAN KEUANGAN PEMERINTAH DAERAH
}

\author{
Bob Mustafa ${ }^{\text {1) }}$ \& Elsa Sari Yuliana ${ }^{2)}$ \\ ${ }^{1}$ Jurusan Akuntansi, Politeknik Negeri Pontianak \\ email: bobkrisna@gmail.com \\ 2 Jurusan Akuntansi, Politeknik Negeri Pontianak \\ email: elsa_sariyuliana@yahoo.com
}

\begin{abstract}
There are still many LKPD opinions in West Kalimantan that have not yet reached WTP opinion, even stagnating from year to year. In addition, the role and function of regional inspectorates in realizing the aspirations of regional governments to obtain WTP opinions that have not been optimal needs to be improved. This study tries to find out the influence of understanding of government accounting standards and understanding of internal control systems in the process of reviewing financial statements in supporting the quality of local government financial reports. This study aims to determine and analyze the influence of the auditor's understanding of accounting standards and internal control systems on the quality of government financial reports through the financial statement review process. This research proves that directly there is a significant influence of Understanding of Government Accounting Standards and Understanding of the Internal Control System towards the Financial Report Review Process. An understanding of the Internal Control System and the Financial Report Review Process has a significant effect on the Quality of Financial Statements. Meanwhile, the understanding of understanding of government accounting standards has no significant effect on the quality of financial statements.
\end{abstract}

Keywords: government accounting standards, internal control system, financial report review process, quality of financial statements.

\section{PENDAHULUAN}

Euforia untuk memperoleh opini WTP dari BPK atas Laporan Keuangan Pemerintah Pusat (LKPP), Laporan Keuangan Kementerian Lembaga (LKKL) dan Laporan Keuangan Pemerintah Daerah (LKPD) menjadi isu yang santer di kalangan Bupati, Walikota, Gubernur, dan Menteri bahkan sampai Presiden. Hal ini bukan sekedar prestige, namun terkait dengan target pemerintah dalam perolehan opini atas laporan keuangan, bahwa pada tahun 2015 opini WTP harus mencapai $60 \%$.
IHPS BPK RI Semester 1 Tahun 2017 mencatat opini WTP (sebesar 84\%) atas LKKL dan LKBUN masih di bawah target Sasaran Pokok Pembangunan Tata Kelola dan Reformasi Birokrasi sebesar 95\% tahun 2019. Indeks opini atas capaian tersebut adalah sebesar 3,70 atau 0,18 poin di bawah target bidang Reformasi Keuangan Negara yang ditetapkan dalam RPJMN 2015-2019 sebesar 3,88. Meskipun capaian indeks opini LKKL di bawah target yang ditetapkan, opini WTP mengalami peningkatan sebesar 19 poin persen dari 65\% pada tahun 2015 menjadi $84 \%$ pada 
tahun 2016. Kenaikan opini WTP tersebut diiringi dengan penurunan atas opini WDP sebesar 21 poin persen, yaitu dari 30\% pada tahun 2015 menjadi 9\% pada tahun 2016. Sedangkan opini TMP mengalami kenaikan 2 poin persen dari 5\% pada tahun 2015 menjadi 7\% pada tahun 2016.

IHPS I Tahun 2017 juga melaporkan hasil pemeriksaan atas 537 Laporan Keuangan Pemerintah Daerah (LKPD) dari 542 LKPD Tahun 2016 yang wajib diserahkan. Hasil pemeriksaan BPK mencatat perolehan opini WTP atas 375 (70\%) LKPD, opini Wajar Dengan Pengecualian (WDP) atas 139 (26\%) LKPD, dan opini Tidak Menyatakan Pendapat (TMP) atas 23 (4\%) LKPD sepert terlihat dalam Grafik 1.1. Capaian opini tersebut telah melampaui target kinerja keuangan daerah bidang penguatan tata kelola pemerintah daerah/program peningkatan kapasitas keuangan pemerintah daerah yang ditetapkan dalam RPJMN 20152019 masing-masing sebesar 85\%, 60\%, dan $65 \%$ di tahun 2019.

\section{Grafik 1. Opini atas LKPD Tahun 2016}

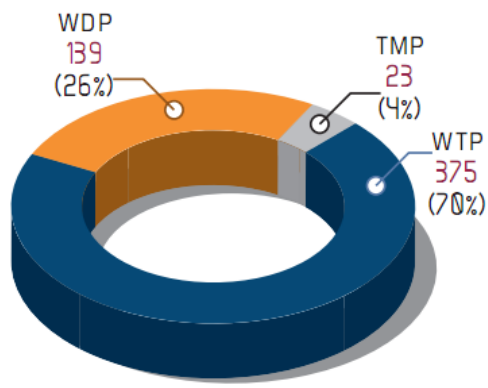

Sumber: IHPS I Tahun 2017 (BPK RI:2017)

Apabila dibandingkan dengan capaian tahun 2015, kualitas LKPD Tahun 2016 mengalami peningkatan yang ditunjukkan dengan kenaikan opini WTP sebesar 12 poin persen yaitu dari $58 \%$ pada LKPD Tahun 2015 menjadi 70\% pada LKPD
Tahun 2016. Pada LKPD Tahun 2015, sebanyak 313 dari 542 LKPD yang memperoleh opini WTP (58\%), sedangkan pada LKPD Tahun 2016 sebanyak 375 dari 537 LKPD yang memperoleh opini WTP (70\%). Selain kenaikan jumlah opini WTP, juga terjadi kenaikan opini dari opini Tidak Wajar (TW) atau TMP menjadi opini WDP sebanyak 15 LKPD.

Dalam 5 tahun terakhir (2012-2016), opini LKPD mengalami perbaikan seperti terlihat dalam Grafik 2.

\section{Grafik 2. Perkembangan Opini LKPD} Tahun 2012-2016

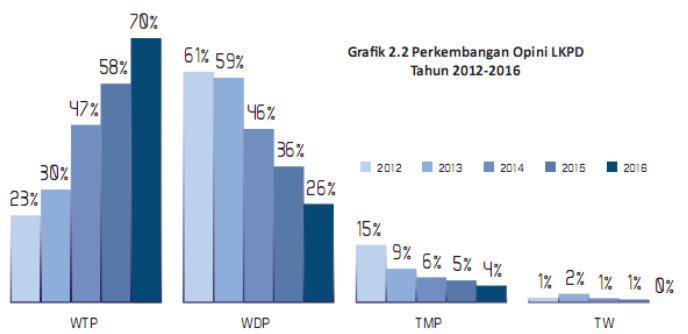

Sumber: IHPS I Tahun 2017 (BPK

RI:2017)

Selama periode 2012-2016, LKPD yang memperoleh opini WTP naik sebanyak 47 poin persen, yaitu dari $23 \%$ pada LKPD Tahun 2012 menjadi 70\% pada LKPD Tahun 2016. Sementara itu, jumlah LKPD yang memperoleh opini TMP mengalami penurunan sebanyak 11 poin persen dari $15 \%$ pada LKPD Tahun 2012 menjadi 4\% pada LKPD Tahun 2016.

Berdasarkan tingkat pemerintahan, opini WTP dicapai oleh 31 dari 34 pemerintah provinsi (91\%), 272 dari 415 pemerintah kabupaten $(66 \%)$, dan 72 dari 93 pemerintah kota (77\%). LKPD Tahun 2016 terdiri atas $34 \mathrm{LK}$ pemprov, $411 \mathrm{LK}$ pemkab, dan 92 LK pemkot. Perkembangan opini LKPD tahun 20122016 berdasarkan tingkat pemda dapat dilihat pada Grafik 3. 
Grafik 3. Opini LKPD Tahun 20122016 berdasarkan Tingkat Pemerintah Daerah

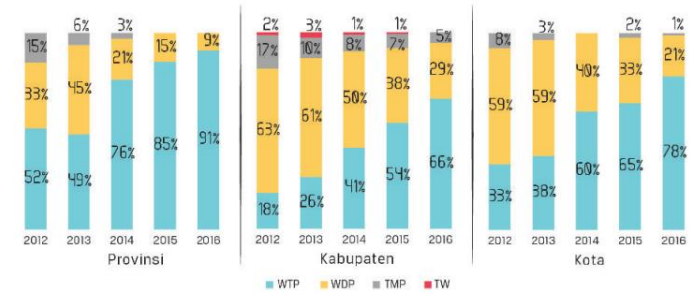

Sumber: IHPS I Tahun 2017 (BPK RI:2017)

Grafik 3 menunjukkan kenaikan opini dari tahun 2015 terjadi pada seluruh tingkat pemda. Pada pemerintah provinsi, opini WTP bertambah dari 29 LKPD (85\%) menjadi 31 LKPD (91\%). Begitu pula untuk pemerintah kabupaten yang bertambah dari 224 LKPD (54\%) menjadi 272 LKPD (66\%), dan pada pemerintah kota dari 60 LKPD $(65 \%)$ menjadi 72 LKPD (78\%).

Kenaikan opini LKPD dikarenakan pemda telah menindaklanjut hasil pemeriksaan BPK tahun 2015 dengan melakukan perbaikan atas kelemahan sistem pengendalian intern maupun ketidakpatuhan terhadap ketentuan peraturan perundang-undangan, sehingga akun-akun dalam laporan keuangan telah disajikan dan diungkapkan sesuai dengan SAP. Sejumlah 162 LKPD yang terdiri atas 139 WDP dan 23 TMP. LKPD yang belum memperoleh opini WTP yang disebabkan masih terdapat akun-akun dalam laporan keuangan yang disajikan tdak sesuai dengan SAP. Akun-akun yang disajikan tdak sesuai dengan SAP disajikan pada Grafik 4.

Grafik 4 memperlihatkan bahwa permasalahan ketidaksesuaian SAP dalam hal penyajian akun dijumpai dalam LKPD Tahun 2016. Ketidaksesuaian akun yang terbanyak adalah dalam penyajian aset tetap, yaitu sebesar $29 \%$.

Pada wilayah Provinsi Kalimantan Barat juga terdapat peningkatan opini selama lima tahun terakhir seperti yang disajikan dalam Tabel 1. Tabel 1 menunjukkan bahwa secara umum pemerintah daerah di provinsi Kalimantan Barat memperoleh opini yang relatif stabil selama lima tahun terakhir. 10 LKPD (60\%) telah berhasil memperoleh opini WPT dan 5 LKPD yang masih belum berhasil mendapatkan opini WTP. 5 LKPD tersebut adalah LKPD Kota Singkawang, Kabupaten Sambas, Kabupaten Bengkayang, Kabupaten Kapuas Hulu, dan Kabupaten Kayong Utara yang masih menyandang predikat Wajar Dengan Pengecualian (WDP) selama 5 tahun berturut-turut. Kepala Perwakilan BPK RI Provinsi Kalimantan Barat dalam siaran pers tanggal 6 Juni 2017 menjelaskan bahwa masih terdapat permasalahanpermasalahan pokok yang menjadi pengecualian opini pada Kabupaten Kapuas Hulu dan Kabupaten Sambas yang memperoleh opini WDP untuk LKPD Tahun 2016 (BPK RI:2017a).

\section{Grafik 4. Akun yang Disajikan Tidak Sesuai dengan SAP pada LKPD Tahun 2016}

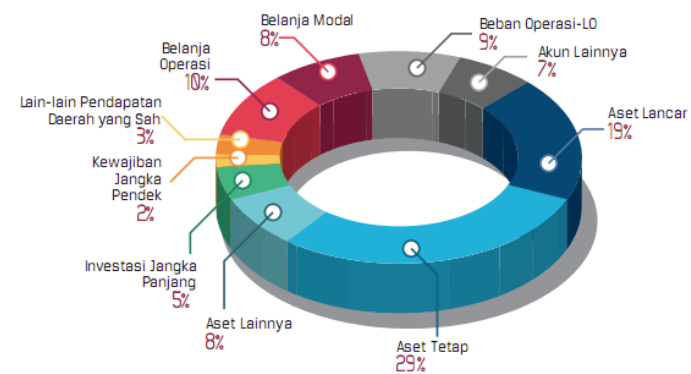

Sumber: IHPS I Tahun 2017 (BPK RI:2017) 
Tabel 1 Opini LKPD Wilayah Kalimantan Barat Tahun 2012-2016

\begin{tabular}{|c|c|c|c|c|c|c|}
\hline No. & Entitas & TA 2012 & TA 2013 & TA 2014 & TA 2015 & TA 2016 \\
\hline 1. & Provinsi Kalimantan Barat & WTP DPP & WTP DPP & WTP & WTP & WTP \\
\hline 2. & Kabupaten Bengkayang & WDP & WDP & WDP & WDP & WDP \\
\hline 3. & Kabupaten Kapuas Hulu & WDP & WDP & WDP & WDP & WDP \\
\hline 4. & Kabupaten Kayong Utara & WDP & WDP & WDP & WDP & WDP \\
\hline 5. & Kabupaten Ketapang & WDP & WDP & WTP DPP & WTP & WTP \\
\hline 6. & Kabupaten Kubu Raya & WDP & WDP & WDP & WTP & WTP \\
\hline 7. & Kabupaten Landak & WDP & WTP DPP & WTP DPP & WTP & WTP \\
\hline 8. & Kabupaten Melawi & WDP & WDP & WDP & WDP & WDP \\
\hline 9. & Kabupaten Mempawah & WDP & WDP & WDP & WDP & WTP \\
\hline 10. & Kabupaten Sambas & WDP & WDP & WDP & WDP & WDP \\
\hline 11. & Kabupaten Sanggau & WDP & WDP & WTP DPP & WTP & WTP \\
\hline 12. & Kabupaten Sekadau & WTP DPP & WTP DPP & WTP DPP & WTP & WTP \\
\hline 13. & Kabupaten Sintang & WTP DPP & WTP DPP & WTP DPP & WTP & WTP \\
\hline 14. & Kota Pontianak & WTP DPP & WTP DPP & WTP DPP & WTP & WTP \\
\hline 15. & Kota Singkawang & WDP & WDP & WDP & WDP & WDP \\
\hline
\end{tabular}

Sumber: Diolah dari IHPS I Tahun 2017 (BPK RI:2017)

Permasalahan pokok yang umum terdapat pada dua entitas ini adalah masalah pengelolaan aset daerah yang belum memadai, antara lain aset tetap yang masih belum ada nilai perolehannya, aset yang pencatatannya digabungkan pada saat perolehannya untuk beberapa item aset, di lain pihak masih juga ada pencatatan aset terutama dari hasil rehab atas aset yang pencatatannya dipisahkan dari aset perolehan awalnya. Pada beberapa entitas masih ditemukan permasalaahn aset yang tidak dapat diketahui dan ditelusuri keberadaannya dan aset-aset yang rusak masih tercatat dalam daftar aset tetap, serta ada juga hasil pengadaan aset yang bersumber dari berbagai jenis bantuan seperti BOS yang belum dicatat (Siaran Pers BPK Provinsi Kalimantan Barat:2017a). Demikian pula dalam siaran pers tanggal 12 Juli 2017 Kepala Perwakilan BPK RI Provinsi Kalimantan Barat menjelaskan bahwa masih terdapat permasalahan-permasalahan pokok yang menjadi pengecualian opini pada empat kabupaten/kota, yaitu Kota Singkawang, Kabupaten Bengkayang, Kabupaten Melawi, dan Kabupaten Kayong Utara yang memperoleh opini WDP untuk
LKPD Tahun 2016 (BPK RI:2017b). Permasalahan pokok yang umum terdapat pada dua entitas ini adalah masalah pengelolaan aset daerah yang belum memadai, antara lain aset tetap yang masih belum ada nilai perolehannya, aset yang pencatatannya digabungkan pada saat perolehannya untuk beberapa item aset, di lain pihak masih juga ada pencatatan aset terutama dari hasil rehab atas aset yang pencatatannya dipisahkan dari aset perolehan awalnya. Pada beberapa entitas masih ditemukan permasalahan aset yang tidak dapat diketahui dan ditelusuri keberadaannya dan aset-aset yang rusak masih tercatat dalam daftar aset tetap, serta penghitungan penyusutan beserta akumulasinya yang belum sesuai ketentuan yang tidak dapat diusulkan koreksinya karena nilai serta informasi asetnya yang belum jelas.

Ketidaksesuaian penyajian akun dalam LKPD selalu menjadi temuan BPK RI dalam pemeriksaan keuangan pemerintah daerah se Indonesia, termasuk pula LKPD kabupaten/kota di wilayah Kalimantan Barat. Tabel 3 menunjukkan perkembangan temuan akun-akun yang penyajiannya tidak sesuai Standar 
Akuntansi Pemerintahan (SAP) pada LKPD di Wilayah Kalimantan Barat.

Tabel 2 menunjukkan bahwa hanya 6 pemerintah daerah yang masih memiliki permasalahan penerapan prinsip akuntansi selama tiga tahun berturutturut, yaitu Kabupaten Bengkayang, Kapuas Hulu, Kayong Utara, Melawi, Sambas, dan Kota Singkawang. Pemerintah Kabupaten Mempawah pada tahun 2016 telah mendapatkan opini WTP dari BPK RI. Hal ini adalah seiring dengani upaya dan perbaikan pengelolaan keuangan yang telah dilakukan Pemerintah Kabupaten Mempawah di tahun 2016 (Siaran Pers BPK Provinsi Kalimantan Barat: 2017a). Usaha enam pemerintah di provinsi Kalimantan Barat untuk menghasilkan laporan keuangan yang berkualitas atau memperoleh opini WTP selama penerapan akuntansi berbasis akrual belum terwujud hingga tahun 2017 dan masih menyisakan kelemahan-kelemahan yang harus diperbaiki. Permasalahan yang menghambat belum diperolehnya opini WTP beragam. Khusus terhadap LKPD, masih terkait dengan pengelolaan kas, pendapatan, dan belanja, serta secara mayoritas disebabkan karena pengelolaan aset tetap yang belum akuntabel. Hal ini mengindikasikan masih banyaknya rekomendasi yang belum sesuai atau dalam proses tindak lanjut dan belum ditindaklanjuti.

Rendahnya penyelesaian tindak lanjut rekomendasi hasil pemeriksaan BPK dapat menjadi indikasi bahwa Pemerintah Daerah belum sepenuhnya berkomitmen dalam melaksanakan rekomendasi tindak lanjut yang diberikan oleh pemeriksa. Upaya yang sungguh-sungguh dari pemerintah daerah untuk memperbaiki temuan-temuan periode sebelumnya akan mengurangi temuan-temuan pada periode selanjutnya. Keadaan ini mengisyaratkan bahwa peran inspektorat daerah dalam mengawal atau memonitor penyelesaian tindak lanjut hasil pemeriksaan BPK RI belum optimal.

Tabel 2. Daftar Penyajian Akun yang Tidak sesuai SAP pada LKPD Wilayah Provinsi Kalimantan Barat Tahun 2014-2016

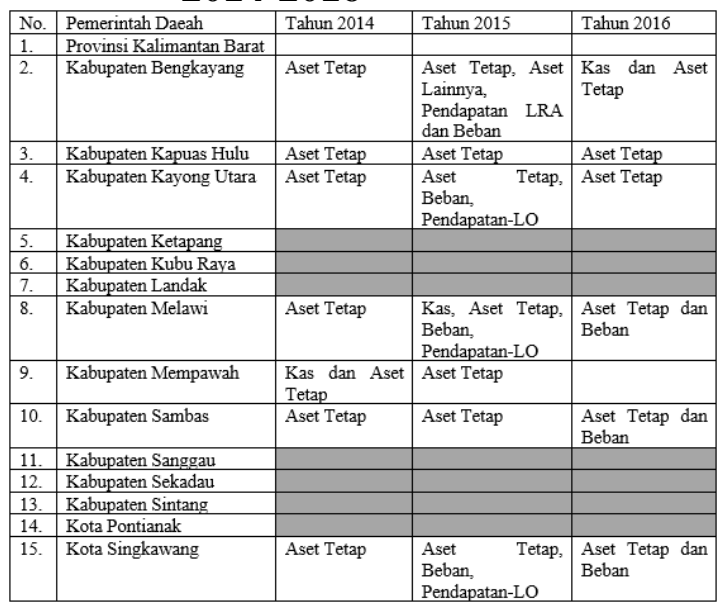

Sumber: Diolah dari IHPS I Tahun 20152017

Arnes (2008) menyebutkan bahwa salah satu faktor penyebab buruknya kualitas laporan keuangan daerah adalah karena masih rendahnya peran inspektorat dalam melakukan fungsi pengawasannya sehingga laporan keuangan tidak memiliki kualitas yang baik sebelum diperiksa oleh BPK. Inspektorat daerah merupakan salah satu faktor kunci keberhasilan pemerintahan daerah dalam pelaksanaan kegiatan pengawasan dan sebagai deteksi awal jika terjadi penyimpangan. Jadi peran inspektorat tidak hanya melakukan pengawasan terhadap kegiatan pengelolaan keuangan daerah saja. Kesalahan dalam penyajian LKPD diharapkan dapat dikurangi dengan adanya reviu. Reviu merupakan komponen penting dari sistem peringatan dini (early warning system) yang diharapkan mampu mengurangi kekeliruan dalam menyajikan informasi keuangan. Reviu yang berkualitas akan dapat meningkatkan kualitas informasi 
yang disajikan dalam LKPD. Menurut Bauwhede (2001), salah satu faktor yang mempengaruhi kualitas laporan keuangan adalah proses reviu laporan keuangan pemerintah daerah oleh inspektorat. Menurut STAN (2007:14), makin baik reviu yang dilakukan oleh Inspektorat akan berpengaruh pada penilaian yang dilakukan BPK atas laporan pertanggungjawaban kepala daerahnya. Dalam melakukan reviu laporan keuangan diperlukan pemahaman tentang SAP. Semakin tinggi/rendah pemahaman terhadap SAP, maka semakin tinggi/rendah peran Inspektorat dalam reviu laporan keuangan daerah (Damanik:2010).

Pemahaman akan standar akuntansi pemerintahan dan sistem pengendalian intern merupakan hal yang penting dalam pelaporan keuangan yang berkualitas. Menurut Susilawati dan Riana (2014), untuk mencapai laporan keuangan yang lebih berkualitas diperlukan pemahaman tentang SAP yang kuat. Begitupun pemahaman tentang sistem pengendalian intern, menurut Krishnan (2005), penekanan pada pengendalian internal yang baik tentu saja muncul karena dianggap sebagai faktor penting dalam mencapai pelaporan keuangan yang berkualitas baik. Selanjunya hasil penelitian Syamsuar (2013) menunjukkan bahwa dengan diterapkannya sistem pengendalian intern akan meningkatkan keandalan laporan keuangan yang merupakan salah satu prasyarat normatif yang diperlukan agar laporan keuangan pemerintah daerah dapat memenuhi kualitas yang dikehendaki.

Berdasar uraian di atas dapat dipahami bahwa inspektorat daerah dalam fungsinya sebagai auditor internal pemerintah daerah memiliki peran strategis untuk mengawal organisasi perangkat daerah atau satuan kerja pemerintah daerah dalam menghasilkan laporan keuangan SKPD dan pemerintah daerah yang berkualitas membutuhkan pemahaman yang baik tentang standar akuntansi pemerintahan dan sistem pengendalian intern. Akuntansi pemerintahan sangat erat kaitan dan dampaknya terhadap sistem pengendalian intern sehingga auditor intern mau tidak mau harus memiliki kemampuan di bidang akuntansi pemerintahan sehingga dapat berperan untuk mendorong penerapan akutansi pemerintahan yang sedang dikembangkan (Simanjuntak:2012).

Penelitian ini penting dilakukan untuk menginvestigasi faktor-faktor yang dominan mempengaruhi kualitas laporan keuangan pemerintah daerah di Kalimantan Barat, mengingat masih banyak opini LKPD di Kalimantan Barat yang belum mencapai opini WTP, bahkan mengalami stagnasi dari tahun ke tahun. Selain itu peran dan fungsi inspektorat daerah dalam mewujudkan citat-cita pemerintah daerah untuk memperoleh opini WTP yang belum optimal perlu disempurnakan. Penelitian ini mencoba untuk mengetahui pengaruh pemahaman standar akuntansi pemerintahan dan pemahaman sistem pengendalian intern dalam proses reviu laporan keuangan dalam mendukung kualitas laporan keuangan pemerintah daerah.

\section{KAJIAN LITERATUR DAN PEGEMBANGAN HIPOTESIS}

\subsection{Kualitas Laporan Keuangan}

Laporan keuangan adalah informasi yang disajikan untuk membantu stakeholders dalam membuat keputusan sosial, politik dan ekonomi sehingga keputusan yang diambil bisa lebih berkualitas (Mahmudi: 2007:11). Karakteristik kualitatif laporan keuangan adalah ukuran-ukuran normatif yang perlu diwujudkan dalam informasi akuntansi sehingga dapat 
memenuhi tujuannya. Menurut Peraturan Pemerintah No. 71 Tahun 2010, Keempat karakteristik berikut ini merupakan prasyarat normatif yang diperlukan agar laporan keuangan pemerintah dapat memenuhi kualitas yang dikehendaki, yaitu: Relevan (memiliki feedback value, memiliki predictive value, tepat waktu, dan lengkap) dan Andal (penyajian jujur, dapat diverifikasi, netral, dapat dibandingkan, dan dapat dipahami).

\subsection{Proses Reviu Laporan Keuangan}

Lampiran I Permendagri Nomor 4 Tahun 2008 menjelaskan Reviu adalah prosedur penelusuran angka-angka dalam laporan keuangan, permintaan keterangan, dan analitik yang harus menjadi dasar memadai bagi Inspektorat untuk memperoleh keyakinan terbatas bahwa tidak ada modifikasi material yang harus dilakukan atas Laporan Keuangan (LK) agar LK tersebut sesuai dengan Standar Akuntansi Pemerintahan (SAP).

Dasar hukum pelaksanaan reviu laporan keuangan oleh inspektorat daerah (APIP) adalah PP No. 60 Tahun 2008. Dengan terbitnya PP No.60 tahun 2008, pengawas intern memiliki peran baru yaitu: Pengawasan intern terhadap akuntabilitas keuangan Negara, pembinaan penyelenggaraan SPIP, dan reviu laporan keuangan pemerintah pusat dan daerah. Dengan paradigma baru ini, tugas pengawas tidak sekedar mengawasi pengelolaan keuangan tetapi bersinergi dengan mitra kerja dalam rangka meningkatkan kualitas laporan keuangan. Selama ini pemerintah kurang memperhatikan pendekatan soft control dalam SPIP tetapi lebih sering merancang SPIP dengan memperkuat pendekatan hard control.

Reviu LKPD diatur dalam berbagai peraturan seperti Permendagri No. 4 Tahun 2008 dan PMK Nomor:
8/PMK.09/2015. Peraturan Menteri Dalam Negeri Nomor 4 tahun 2008 tentang Pedoman Pelaksanaan Reviu atas Laporan Keuangan Pemerintah Daerah Reviu atas Laporan Keuangan Pemerintah Daerah (LKPD) adalah prosedur penelusuran angka-angka, permintaan keterangan, dan analitis yang harus menjadi dasar memadai bagi Inspektorat untuk memberi keyakinan terbatas atas laporan keuangan bahwa tidak ada modifikasi material yang harus dilakukan atas laporan keuangan agar LK tersebut disajikan berdasarkan SPI yang memadai dan sesuai dengan standar akuntansi pemerintahan. Pasal 2 ayat (1) menyatakan ruang lingkup reviu atas laporan keuangan pemerintah daerah meliputi penilaian terbatas terhadap keandalan sistem pengendalian intern dan kesesuaian dengan standar akuntansi pemerintahan. Tujuan reviu LKPD menurut Pasal 4 dalam peraturan ini adalaj untuk memberikan keyakinan terbatas bahwa laporan keuangan pemerintah daerah disusun berdasarkan sistem pengendalian intern yang memadai dan disajikan sesuai dengan standar akuntansi pemerintahan.

Bab V Permendagri No. 4 Tahun 2008 menjelaskan proses reviu laporan keuangan yang meliputi tahap perencanaan (pasal 5-11), pelaksanaan (pasal 12-16), dan pelaporan (pasal 1720).

\subsection{Standar Akuntansi Pemerintahan}

Standar akuntansi pemerintahan di Indonesia diatur dalam PP No. 71 Tahun 2010 tentang Standar Akuntansi Pemerintahan. Pasal 1 PP Nomor 71 tahun 2010 menyatakan bahwa Standar Akuntansi Pemerintah yang selanjutnya disebut SAP adalah prinsip-prinsip akuntansi yang diterapkan dalam menyusun dan menyajikan laporan keuangan pemerintah. 
Standar Akuntansi Pemerintahan merupakan persyaratan yang memiliki kekuatan hukum dalam upaya meningkatkan kualitas laporan keuangan pemerintah di Indonesia. Selain itu, Standar Akuntansi Pemerintahan juga bertujuan untuk meningkatkan akuntabilitas dan keandalan pengelolaan laporan keuangan pemerintah melalui penyusunan dan pengembangan standar akuntansi pemerintah, termasuk mendukung pelaksanaan penerapan standar tersebut.

Standar Akuntansi Pemerintahan diterapkan dalam lingkup pemerintahan, yaitu Pemerintahan Pusat, Pemerintahan Daerah, dan satuan organisasi di lingkungan Pemerintahan Pusat/Daerah, jika menurut peraturan perundangundangan satuan organisasi yang dimaksud wajib menyajikan laporan keuangan.

\subsection{Sistem Pengendalian Intern}

Pengertian sistem pengendalian intern menurut Peraturan Pemerintah No. 60 Tahun 2008 adalah sistem Pengendalian Intern adalah proses yang integral pada tindakan dan kegiatan yang dilakukan secara terus menerus oleh pimpinan dan seluruh pegawai untuk memberikan keyakinan memadai atas tercapainya tujuan organisasi melalui kegiatan yang efektif dan efisien, keandalan pelaporan keuangan, pengamanan asset negara dan ketaatan terhadap peraturan perundang-undangan. Sementara menurut I Gusti Agung Rai (2008:283) "Sistem pengendalian intern adalah kebijakan dan prosedur yang dirancang untuk memberikan keyakinan yang memadai bagi manajemen bahwa organisasi mencapai tujuan dan sasarannya."

Unsur-unsur Sistem Pengendalian Intern Unsur sistem pengendalian intern yang berfungsi sebagai pedoman penyelenggaraan dan tolak ukur pengujian efektivitas penyelenggaraan system pengendalian intern. Menurut Peraturan Pemerintah No.60 Tahun 2008 bahwa unsur sistem pengendalian intern dalam Peraturan Pemerintah ini mengacu pada unsur Sistem Pengendalian Intern yang telah dipraktikan di lingkungan pemerintah di berbagai Negara, yang meliputi lingkungan pengendalian, penilaian risiko, kegiatan pengendalian, informasi; dan komunikasi, dan pemantauan.

\subsection{Hubungan Pemahaman tentang Standar Akuntansi Pemerintahan dengan Proses Reviu Laporan Keuangan Pemerintah Daerah Oleh Inspektorat}

Reviu sendiri adalah prosedur penelusuran angka-angka dalam laporan keuangan, permintaan keterangan, dan analitik yang harus menjadi dasar memadai bagi Inspektorat untuk memperoleh keyakinan terbatas bahwa tidak ada modifikasi material yang harus dilakukan atas laporan keuangan agar laporan keuangan tersebut sesuai dengan Standar Akuntansi Pemerintahan (SAP). Pemahaman pereviu tentang standar akuntansi akuntansi pemerintahan merupakan modal dasar bagi auditor inspektorat daerah dalam melaksanakan reviu laporan keuangan pemerintah daerah untuk agar tujuan reviu untuk memberikan keyakinan terbatas bahwa laporan keuangan pemerintah daerah telah disusun sesuai standar akuntansi pemerintahan.

Hasil penelitian sebelumnya seperti yang dilakukan oleh Damanik (2010), baik secara simultan maupun secara parsial menunjukkan bahwa pemahaman terhadap standar akuntansi pemerintahan berpengaruh secara signifikan terhadap peran inspektorat dalam reviu laporan keuangan pemerintah daerah. Menurutnya, semakin tinggi/rendah pemahaman terhadap SAP, maka semakin tinggi/rendah peran Inspektorat 
dalam reviu laporan keuangan daerah. Hasil penelitian Manaf (2014) menunjukkan bahwa pemahaman tentang standar akuntansi pemerintahan berpengaruh terhadap proses reviu laporan keuangan pemerintah daerah oleh inspektorat.

Berdasarkan penjelasan di atas, hipotesis dalam penelitian ini dirumuskan sebagai berikut:

H1: Pemahaman tentang standar akuntansi pemerintahan berpengaruh terhadap proses reviu laporan keuangan

\subsection{Hubungan Pemahaman tentang Sistem Pengendalian Intern dengan Proses Reviu Laporan Keuangan Pemerintah Daerah Oleh Inspektorat}

Pemahaman pereviu atas pengendalian internal akan mempermudah pendeteksian dan pengungkapan masalah yang ditemukan dalam pelaksanaan reviu, pemahaman tersebut akan memungkinkan pereviu menyusun rekomendasi yang tepat agar masalah yang terjadi tidak terulang kembali dimasa yang akan dating, sehingga pemahaman SPI merupakan suatu hal yang mutlak dibutuhkan untuk mendapatkan kualitas reviu (STAN, 2007b:65-68). Oleh karena itu, Pemahaman tentang Sistem Pengendalian Intern diduga dapat mempengaruhi proses reviu laporan keuangan pemerintah daerah oleh inspektorat. Menurut Peraturan Menteri Dalam Negeri Nomor 4 Tahun 2008 tentang Pedoman Pelaksanaan Reviu atas Laporan Keuangan Pemerintah Daerah, reviu adalah prosedur penelusuran angkaangka dalam laporan keuangan, permintaan keterangan, dan analitik yang harus menjadi dasar memadai bagi Aparat Pengawasan Intern Pemerintah (APIP) untuk memberi keyakinan terbatas bahwa tidak ada modifikasi material yang harus dilakukan atas laporan keuangan agar laporan keuangan tersebut disajikan berdasarkan Sistem Pengendalian Intern (SPI) yang memadai dan sesuai dengan Standar Akuntansi Pemerintahan (SAP). Penilaian atas sistem pengendalian intern merupakan salah satu dari tiga proses dalam tahapan perencanaan reviu laporan keuangan. Penilaian atas SPI dalam tahapan perencanaan reviu ini berguna untuk mengidentifikasi prosedur-prosedur pengelolaan keuangan daerah yang mempunyai resiko untuk terjadinya salah saji secara material dalam penyusunan laporan keuangan.

Hasil penelitian sebelumnya seperti yang dilakukan oleh Manaf (2014) menunjukkan bahwa pemahaman terhadap system pengendalian intern berpengaruh terhadap proses reviu laporan keuangan pemerintah daerah.

Berdasarkan penjelasan di atas, hipotesis dalam penelitian ini dirumuskan sebagai berikut:

H2 : Pemahaman tentang sistem pengendalian intern berpengaruh terhadap proses reviu laporan keuangan

\subsection{Hubungan Pemahaman tentang Standar Akuntansi Pemerintahan dengan Kualitas Laporan Keuangan}

Untuk menghasilkan laporan keuangan yang berkualitas, diperlukan pemahaman terhadap standar akuntansi pemerintahan yang telah ditetapkan oleh pemerintah. Shahwan (2008) menyatakan bahwa kualitas laporan keuangan dapat dipenuhi jika tingkat kemahiran dan persiapan pelaporan keuangan didasarkan sepenuhnya pada Standar Akuntansi Pemerintahan. Hasil penelitian sebelumnya seperti yang dilakukan oleh Syamsuar (2013) yang melakukan penelitian pada SKPK Aceh Besar menunjukkan bahwa pemahaman tentang SAP berpengaruh terhadap kualitas laporan keuangan 
daerah, dimana setiap kenaikan pemahaman tentang SAP maka akan diikuti dengan kenaikan kualitas laporan keuangan daerah. Hasil penelitian yang sama juga terjadi pada penelitian yang dilakukan oleh Susilawati dan D.S. Riana (2014) yang menyimpulkan bahwa standar akuntansi pemerintahan berpengaruh positif terhadap kualitas laporan keuangan pemerintah daerah, sehingga diperlukan pemahaman tentang standar akuntansi pemerintahan yang kuat untuk mencapai laporan keuangan yang lebih berkualitas. Oleh karena itu, pemahaman tentang standar akuntansi pemerintahan diduga dapat mempengaruhi kualitas laporan keuangan pemerintah daerah. Hasil penelitian Manaf (2014) menunjukkan bahwa pemahaman tentang standar akuntansi pemerintahan berpengaruh terhadap kualitas laporan keuangan pemerintah daerah kab/kota di Provinsi Aceh.

Berdasarkan penjelasan di atas, hipotesis dalam penelitian ini dirumuskan sebagai berikut:

H3 : Pemahaman tentang standar akuntansi pemerintahan berpengaruh terhadap kualitas laporan keuangan

\subsection{Hubungan Pemahaman tentang Sistem Pengendalian Intern dengan Kualitas Laporan Keuangan}

Menurut Peraturan Pemerintah Nomor 60 Tahun 2008, sistem pengendalian intern adalah proses yang integral pada tindakan dan kegiatan yang dilakukan secara terus menerus oleh pimpinan dan seluruh pegawai untuk memberikan keyakinan memadai atas tercapainya tujuan organisasi melalui kegiatan yang efektif dan efisien, keandalan pelaporan keuangan, pengamanan aset negara dan ketaatan terhadap peraturan perundangundangan. Sistem pengendalian Intern melalui lingkungan pengendalian dapat meningkatkan kualitas laporan keuangan dalam hal mengurangi kesalahan pelaporan (Gordon and Smith, 1992).

Hasil penelitian yang dilakukan oleh (Susilawati dan Riana, 2014; Hidayat, 2014) menunjukkan bahwa sistem pengendalian intern berpengaruh terhadap kualitas laporan keuangan. Demikian pula hasil penelitian Syamsuar (2013) menunjukkan bahwa dengan diterapkannya sistem pengendalian intern akan meningkatkan keandalan laporan keuangan yang merupakan salah satu prasyarat normatif yang diperlukan agar laporan keuangan pemerintah daerah dapat memenuhi kualitas yang dikehendaki. Sebelumnya, penelitian Yunidar (2011) dan Suhaili (2012) telah membuktikan bahwa sistem pengendalian intern berpengaruh terhadap kualitas laporan keuangan. Hasil penelitian Irmawati (2013) menunjukkan bahwa faktorfaktor SPIP mempengaruhi kualitas laporan keuangan. Oleh karena itu, pemahaman tentang SPI diduga dapat mempengaruhi kualitas laporan keuangan pemerintah daerah. Berbeda dengan hasil penelitian Manaf (2014) yang menunjukkan bahwa pemahaman sistem

pengendalian intern tidak berpengaruh terhadap kualitas laporan keuangan pemerintah daerah.

Berdasarkan penjelasan di atas, hipotesis dalam penelitian ini dirumuskan sebagai berikut:

H4: Pemahaman tentang sistem pengendalian intern berpengaruh terhadap kualitas laporan keuangan

Mengacu pada uraian kerangka pemikiran dan pengembangan hipotesis di atas, maka rancangan model penelitian dapat digambarkan sebagai berikut: 


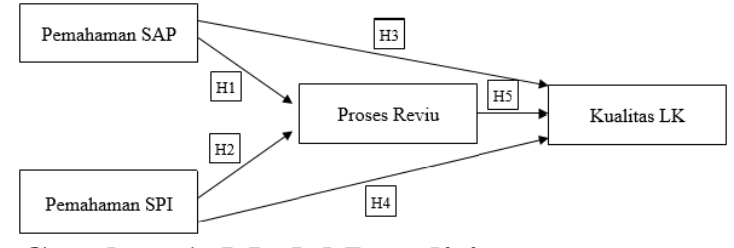

Gambar 1. Model Penelitian

\section{METODE PENELITIAN}

\subsection{Operasionalisasi Variabel}

Variabel dependen dan variabel independen dalam penelitian ini diikhtisarkan dalam Tabel 2 berikut ini:

Tabel 3. Operasionalisasi Variabel

\begin{tabular}{|c|c|c|c|}
\hline Variabel & Definisi & Indikator & Skala \\
\hline $\begin{array}{l}\text { Kualitas Laporan } \\
\text { Keuangan } \\
\text { (Z) }\end{array}$ & \begin{tabular}{|l|} 
Kualitas laporan keuangan \\
adalah laporan keuangan \\
yang memenuhi karakteristik \\
kualitatif laporan keuangan \\
(PP nomor 71 tahun 2010)
\end{tabular} & $\begin{array}{l}\text { 1. Relevan } \\
\text { 2. Andal } \\
\text { 3. Dapat dibandingkan } \\
\text { 4. Dapat dipahami. }\end{array}$ & Likert \\
\hline $\begin{array}{l}\text { Proses Reviu } \\
\text { Laporan } \\
\text { Keuangan } \\
\text { (Y) }\end{array}$ & \begin{tabular}{|l|} 
Proses reviu laporan \\
keuangan adalah tahapan \\
yang dilalui selama \\
melakukan reviu laporan \\
keuangan pemerintah daerah \\
(Peraturan Menteri \\
Dalam Negeri nomor 4 tahun \\
2008) \\
\end{tabular} & $\begin{array}{l}\text { 1. Tahap Perencanaan } \\
\text { 2. Tahap pelaksanaan } \\
\text { 3. Tahap pelaporan }\end{array}$ & Likert \\
\hline $\begin{array}{l}\text { Sistem } \\
\text { Pengendalian } \\
\text { Intern } \\
(\mathrm{X} \mid)\end{array}$ & $\begin{array}{l}\text { Pemahaman pereviu dalam } \\
\text { SPI adalah kemampuan } \\
\text { memahami terhadap } \\
\text { unsur-unsur sistem } \\
\text { pengendalian intern } \\
\text { (Peraturan Pemerintah nomor } \\
60 \text { tahun 2008) }\end{array}$ & \begin{tabular}{|l} 
1. Pemahaman terhadap \\
Lingkungan \\
pengendalian \\
2. Pemahaman terhadap \\
Penilaian risiko \\
3. Pemahaman terhadap \\
kegiatan pengendalian \\
4. Pemahaman terhadap \\
informasi dan \\
komunikasi \\
5. Pemahaman terhadap \\
pemantauan
\end{tabular} & Likert \\
\hline $\begin{array}{l}\text { Standar } \\
\text { Akuntansi } \\
\text { Pemerintahan } \\
\text { (X2) }\end{array}$ & $\begin{array}{l}\text { Pemahaman pereviu dalam } \\
\text { SAP adalah kemampuan } \\
\text { memahami terhadap } \\
\text { penyajian, komponen, } \\
\text { pengakuan dan pengukuran } \\
\text { unsur-unsur laporan keuangan } \\
\text { serta } \\
\text { koreksi kesalahan dan laporan } \\
\text { keuangan konsolidasian } \\
\text { (Peraturan } \\
\text { Pemerintah nomor } 71 \text { tahun } \\
\text { 2010). }\end{array}$ & \begin{tabular}{|l|} 
1. Pemahaman terhadap \\
Penyajian laporan \\
keuangan \\
2. Pemahaman tentang \\
komponen dalam \\
laporan keuangan \\
3. Pemahaman tentang \\
pengakuan unsur \\
laporan keuangan \\
4. Pemahaman tentang \\
pengukuran unsur \\
laporan keuangan \\
5. Pemahaman tentang \\
koreksi kesalahan, \\
perubahan kebijakan \\
akuntansi dan \\
peristiwa luar biasa \\
6. Pemahaman tentang \\
laporan keuangan \\
konsolidasian
\end{tabular} & Likert \\
\hline
\end{tabular}

\subsection{Populasi dan Sampel}

Populasi dalam penelitian ini adalah auditor inspektorat daerah pada 15 inspektorat daerah kabupaten/kota dan provinsi di Kalimantan Barat yang terlibat dalam reviu laporan keuangan pemerintah daerahnya. Teknik pemilihan sampel menggunakan metode sampling kuota (quota sampling). Kriteria pemilihan sampel atau responden penelitian ini adalah seluruh pejabat fungsional auditor dan P2UPD yang terlibat dalam reviu LKPD pada masingmasing inspektorat daerah Jumlah sampel penelitian yang menjadi responden penelitian pada tiap inspektorat daerah diambil sebanyak 12 orang. Sehingga jumlah responden pada 15 inspektorat daerah adalah sebanyak 180 orang.

\subsection{Alat Analisis}

Kuesioner yang terkumpul sebanyak 97 kuesioner (dari 180 kuesioner yang disebar), namun hanya 93 kuesioner yang dapat diolah. Uji validitas dan uji reliabilitas instrument dan uji asumsi klasik dilakukan sebelum dilakukan analisis jalur dengan menggunakan SPSS versi 23.

\section{HASIL}

\subsection{Demografi Responden}

Penelitian ini menggunakan data primer yang diperoleh dari penyebaran kuesioner kepada 180 responden, yaitu seluruh pejabat fungsional Auditor dan P2UPD yang pernah menjadi anggota tim reviu LKPD pada 15 inspektorat daerah provinsi, kabupaten, dan kota di Kalimantan Barat. Hingga batas akhir pengumpulan data, kuesioner yang diterima kembali adalah sebanyak 97 kuisioner dari 180 kuisioner yang disebarkan atau sebanyak 53,89\%. Dari jumlah tersebut, kuesioner yang dapat diolah adalah sebanyak 93 kuesioner atau $51,67 \%$.

\subsection{Koefisien Jalur Model I}

Mengacu pada output Regresi Model I seperti yang disajikan pada Tabel 4, diketahui bahwa nilai signifikansi variabel Pemahaman tentang Standar Akuntansi Pemerintahan (X1) sebesar 0,002 dan variabel Pemahaman tentang Sistem Pengendalian Intern (X2) sebesar 0,003 yang nilainya $<0,05$. Hasil ini memberikan simpulan bahwa pada 
Regresi Model I, variable X1 (Pemahaman tentang Standar Akuntansi Pemerintahan) dan variable X2 (Pemahaman tentang Sistem Pengendalian Intern) berpengaruh signifikan terhadap Y (Proses Reviu Laporan Keuangan).

Nilai R Square yang terdapat dalam tabel Model Summary atau Table 5 adalah sebesar 0,335. Hal ini menunjukkan bahwa sumbangan pengaruh variabel Pemahaman tentang Standar Akuntansi Pemerintahan (X1) dan variabel Pemahaman tentang Sistem Pengendalian Intern (X2) terhadap variable Proses Reviu Laporan Keuangan (Y) adalah sebesar 33,5\%, sementara sisanya $66,5 \%$ merupakan kontribusi dari variabel-variabel lain yang tidak dimasukkan dalam penelitian ini. Nilai e1 dapat diperoleh dengan rumus el $=\sqrt{ }(1-$ $0,335)=0,8155$.

\section{Tabel 4 Koefisien Jalur Model I}

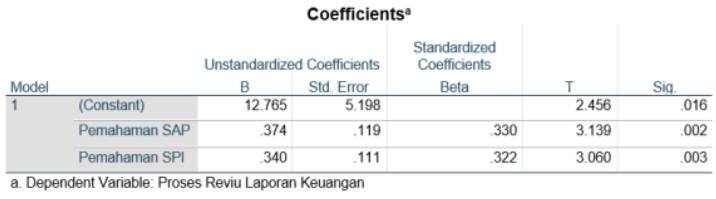

\section{Tabel 5. R Square Model I}

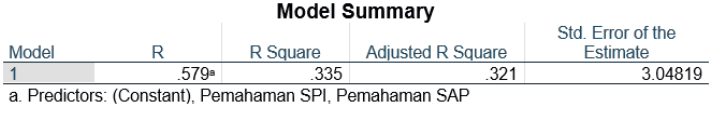

Berdasarkan nilai Standardized Coefficients Beta dan nilai $\mathrm{R}$ Square, serta nilai e1 pada Model I di atas, maka dihasilkan diagram jalur Model I seperti di bawah ini.

\section{Gambar 2 Diagram Jalur Model I}

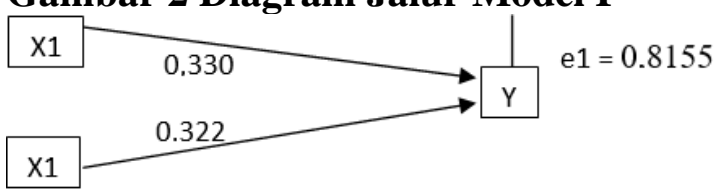

\subsection{Koefisien Jalur Model II}

Berdasarkan output Regresi Model II seperti yang disajikan pada Tabel 6, diketahui bahwa nilai signifikansi ketiga variabel, yaitu variabel Pemahaman tentang Standar Akuntansi Pemerintahan (X1) sebesar 0,329, Pemahaman tentang Sistem Pengendalian Intern (X2) sebesar 0,012, dan Proses Reviu Laporan Keuangan (Y) sebesar 0.003. Nilai signifikansi X1 sebesar 0,329 adalah > 0,05 , yang artinya Pemahaman tentang Standar Akuntansi Pemerintahan tidak berpengaruh terhadap variable Kualitas Laporan Keuangan (Z), sedangkan nilai signifikansi variable X2 dan Y adalah < 0,05 , yang berarti kedua variable ini (Pemahaman tentang Sistem Pengendalian Intern dan Proses Reviu Laporan Keuangan) berpengaruh signifikan terhadap Kualitas Laporan Keuangan (Z).

Nilai R Square yang terdapat dalam Tabel 7 adalah sebesar 0,354. Hal ini menunjukkan bahwa sumbangan pengaruh variabel Pemahaman tentang Standar Akuntansi Pemerintahan (X1) dan variabel Pemahaman tentang Sistem Pengendalian Intern (X2) terhadap variable Proses Reviu Laporan Keuangan (Y) adalah sebesar $35,4 \%$, sementara sisanya $64,6 \%$ merupakan kontribusi dari variabel-variabel lain yang tidak dimasukkan dalam penelitian ini. Nilai e2 dapat diperoleh dengan rumus e $2=\sqrt{ }(1$ $0,354)=0,8037$.

\section{Tabel 6. Koefisien Jalur Model II}

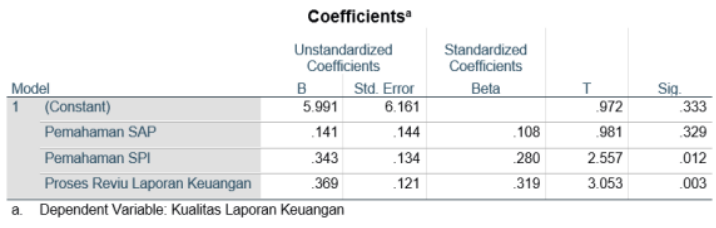

\section{Tabel 7. R Square Model II}

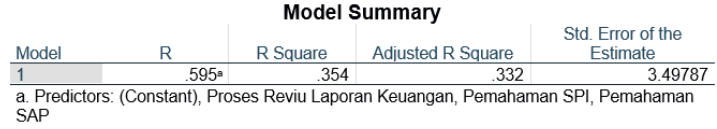

Berdasarkan nilai Standardized Coefficients Beta dan nilai $\mathrm{R}$ Square, serta nilai e2 pada Model II di atas, maka 
dihasilkan diagram jalur Model II seperti di bawah ini.

Gambar 3 Diagram Jalur Model II

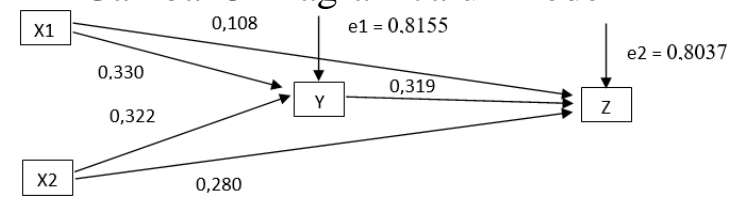

\section{PEMBAHASAN}

\subsection{Pengaruh Pemahaman tentang Standar Akuntansi Pemerintahan terhadap Proses Reviu Laporan Keuangan}

Nilai signifikansi variabe $\mathrm{X} 1$ (Pemahaan tentang Standar Akuntansi Pemerintahan) sebesar $0,002<0,05$ sehingga dapat dapat diartikan bahwa secara langsung terdapat pengaruh signifikan Pemahaman tentang Standar Akuntansi Pemerintahan terhadap Proses Reviu Laporan Keuangan (Y). Dengan demikian, maka Hipotesis 1 (pengaruh Pemahaman tentang Standar Akuntansi Pemerintahan terhadap Proses Reviu Laporan Keuangan) dapat diterima. Hasil penelitian ini senada dengan penelitian Damanik (2010) dan Manaf (2014) bahwa pemahaman tentang standar akuntansi pemerintahan berpengaruh terhadap proses reviu laporan keuangan pemerintah daerah oleh inspektorat.

\subsection{Pengaruh Pemahaman tentang Sistem Pengendalian Intern terhadap Proses Reviu Laporan Keuangan}

Nilai signifikansi variable $\mathrm{X} 2$ (Pemahaan tentang Sistem Pengendalian Intern) sebesar 0,003 $<0,05$ sehingga dapat dapat diartikan bahwa secara langsung terdapat pengaruh signifikan Pemahaman tentang Sistem Pengendalian Intern terhadap Proses Reviu Laporan Keuangan (Y). Dengan demikian, maka Hipotesis 2 (pengaruh Pemahaman tentang Sistem Pengendalian Intern terhadap Proses Reviu Laporan
Keuangan) dapat diterima. Hasil penelitian ini mendukung penelitian yang dilakukan oleh Manaf (2014) bahwa pemahaman auditor inspektorat akan sistem pengendalian intern berpengaruh terhadap proses reviu laporan keuangan pemerintah daerah.

\subsection{Pengaruh Pemahaman tentang Standar Akuntansi Pemerintahan terhadap Kualitas Laporan Keuangan}

Nilai signifikansi variable $\mathrm{X} 1$ (Pemahaan tentang Standar Akuntansi Pemerintahan) sebesar $0,329>0,05$ sehingga dapat dapat diartikan bahwa secara langsung tidak terdapat pengaruh signifikan Pemahaman tentang Pemahaan tentang Standar Akuntansi Pemerintahan terhadap Kualitas Laporan Keuangan (Z). Dengan demikian, maka Hipotesis 3 (pengaruh Pemahaman tentang Standar Akuntansi Pemerintahan terhadap Kualitas Laporan Keuangan) ditolak. Hasil penelitian ini mendukung penelitian Syamsuar (2013), Susilawati \& Riana (2014), serta Manaf (2014) yang menunjukkan bahwa pemahaman terhadap sistem pengendalian intern berpengaruh terhadap proses reviu laporan keuangan pemerintah daerah.

\subsection{Pengaruh Pemahaman tentang Sistem Pengendalian Intern terhadap Kualitas Laporan Keuangan}

Nilai signifikansi variable X2 (Pemahaan tentang Sistem Pengendalian Intern) sebesar 0,012 < 0,05 sehingga dapat dapat diartikan bahwa secara langsung terdapat pengaruh signifikan Pemahaman tentang Sistem Pengendalian Intern terhadap Kualitas Laporan Keuangan (Z). Dengan demikian, maka Hipotesis 4 (pengaruh Pemahaman tentang Sistem Pengendalian Intern terhadap Kualitas Laporan Keuangan) dapat diterima. Hasil penelitian ini 
senada dengan penelitian Yunidar (2011), Suhaili (2012), Irmawati (2013), Susilawati dan Riana (2014), Hidayat (2014), dan Syamsuar (2013). Hasil penelitian ini tidak mendukung penelitian Manaf (2014) yang menunjukkan bahwa pemahaman sistem pengendalian intern tidak berpengaruh terhadap kualitas laporan keuangan pemerintah daerah.

\subsection{Pengaruh Proses Reviu Laporan Keuangan terhadap Kualitas Laporan Keuangan}

Nilai signifikansi variable Y (Proses Reviu Laporan Keuangan) sebesar 0,003 $<0,05$ sehingga dapat dapat diartikan bahwa secara langsung terdapat pengaruh signifikan Proses Reviu Laporan Keuangan terhadap Kualitas Laporan Keuangan (Z). Dengan demikian, maka Hipotesis 5 (pengaruh Proses Reviu Laporan Keuangan terhadap Kualitas Laporan Keuangan) dapat diterima. Hasil penelitian ini mendukung penelitian Kesuma dkk. (2014) yang membuktikan bahwa peningkatan nilai informasi pelaporan keuangan pemda memerlikan peran internal auditor untuk mereviu laporan keuangan pemerintah daerah.

\section{SIMPULAN}

Penelitian ini bertujuan untuk mendapatkan bukti empiris mengenai pengaruh pemahaman auditor inspektorat daerah tentang standar akuntansi pemerintahan dan sistem pengendalian intern dalam proses reviu laporan keuangan dan implikasinya pada kualitas aporan keuangan pemerintah kabupaten/kota se-Kalimantan Barat. Hasil penelitian menunjukkan bahwa:

1. Nilai signifikansi variabe $\mathrm{X} 1$ (Pemahaan tentang Standar Akuntansi Pemerintahan) sebesar 0,002 $<0,05$ sehingga dapat dapat diartikan bahwa secara langsung terdapat pengaruh signifikan Pemahaman tentang
Standar Akuntansi Pemerintahan terhadap Proses Reviu Laporan Keuangan (Y). Dengan demikian, maka Hipotesis 1 (pengaruh Pemahaman tentang Standar Akuntansi Pemerintahan terhadap Proses Reviu Laporan Keuangan) dapat diterima.

2. Nilai signifikansi variable X2 (Pemahaan tentang Sistem Pengendalian Intern) sebesar 0,003 < 0,05 sehingga dapat dapat diartikan bahwa secara langsung terdapat pengaruh signifikan Pemahaman tentang Sistem Pengendalian Intern terhadap Proses Reviu Laporan Keuangan (Y). Dengan demikian, maka Hipotesis 2 (pengaruh Pemahaman tentang Sistem Pengendalian Intern terhadap Proses Reviu Laporan Keuangan) dapat diterima.

3. Nilai signifikansi variable X1 (Pemahaan tentang Standar Akuntansi Pemerintahan) sebesar 0,329>0,05 sehingga dapat dapat diartikan bahwa secara langsung tidak terdapat pengaruh signifikan Pemahaman tentang Pemahaan tentang Standar Akuntansi Pemerintahan terhadap Kualitas Laporan Keuangan (Z). Dengan demikian, maka Hipotesis 3 (pengaruh Pemahaman tentang Standar Akuntansi Pemerintahan terhadap Kualitas Laporan Keuangan) ditolak.

4. Nilai signifikansi variable X2 (Pemahaan tentang Sistem Pengendalian Intern) sebesar 0,012 < 0,05 sehingga dapat dapat diartikan bahwa secara langsung terdapat pengaruh signifikan Pemahaman tentang Sistem Pengendalian Intern terhadap Kualitas Laporan Keuangan (Z). Dengan demikian, maka Hipotesis 4 (pengaruh Pemahaman tentang Sistem Pengendalian Intern 
terhadap Kualitas Laporan Keuangan) dapat diterima.

5. Nilai signifikansi variable $\mathrm{Y}$ (Proses Reviu Laporan Keuangan) sebesar $0,003<0,05$ sehingga dapat dapat diartikan bahwa secara langsung terdapat pengaruh signifikan Proses Reviu Laporan Keuangan terhadap Kualitas Laporan Keuangan (Z). Dengan demikian, maka Hipotesis 5 (pengaruh Proses Reviu Laporan Keuangan terhadap Kualitas Laporan Keuangan) dapat diterima.

\section{REFERENSI}

Arens, Alvin A. 2008. Auditing dan Jasa Assurance Pendekatan Terintegrasi Jilid I. Erlangga. Jakarta.

Arnes, D. 2008. Menunggu Peran Inspektorat dalam Reviu Laporan Keuangan Daerah. Majalah Pemeriksaan BPK RI No 116/Edisi Khusus.

Badan Pemeriksa Keuangan Republik Indonesia. 2010. Peraturan Badan Pemeriksaan Keuangan Republik Indonesia Nomor 2 Tentang Pemantauan Tindak Lanjut Hasil Pemeriksaan. Jakarta: Penerbitan BPK-RI.

Badan Pemeriksa Keuangan Republik Indonesia. 2011. Ikhtisar Hasil Pemeriksaan Semester I 2011. September 2011. Jakarta: Penerbitan BPK-RI.

Badan Pemeriksa Keuangan Republik Indonesia. 2012. Ikhtisar Hasil Pemeriksaan Semester I 2012. September 2012. Jakarta: Penerbitan BPK-RI.
Badan Pemeriksa Keuangan Republik Indonesia. 2012. Ikhtisar Hasil Pemeriksaan Semester II 2011. Maret 2012. Jakarta: Penerbitan BPK-RI.

Badan Pemeriksa Keuangan Republik Indonesia. 2013. Ikhtisar Hasil Pemeriksaan Semester I 2013. September 2013. Jakarta: Penerbitan BPK-RI.

Badan Pemeriksa Keuangan Republik Indonesia. 2013. Ikhtisar Hasil Pemeriksaan Semester II 2012. Maret 2014. Jakarta: Penerbitan BPK-RI.

Badan Pemeriksa Keuangan Republik Indonesia. 2014. Ikhtisar Hasil Pemeriksaan Semester II 2013. Maret 2014. Jakarta: Penerbitan BPK-RI.

Badan Pemeriksa Keuangan Republik Indonesia. 2015. Ikhtisar Hasil Pemeriksaan Semester I 2015. September 2015. Jakarta: Penerbitan BPK-RI.

Badan Pemeriksa Keuangan Republik Indonesia. 2015. Ikhtisar Hasil Pemeriksaan Semester II 2014. Maret 2015. Jakarta: Penerbitan BPK-RI.

Badan Pemeriksa Keuangan Republik Indonesia. 2015. Ikhtisar Hasil Pemeriksaan Semester I 2014, Buku I Ringkasan Eksekutif, September 2014. Jakarta: Penerbitan BPK-RI.

Badan Pemeriksa Keuangan Republik Indonesia. 2016. Ikhtisar Hasil Pemeriksaan Semester I 2016. September 2016. Jakarta: Penerbitan BPK-RI. 
Badan Pemeriksa Keuangan Republik Indonesia. 2016. Ikhtisar Hasil Pemeriksaan Semester II 2015. Maret 2016. Jakarta: Penerbitan BPK-RI.

Badan Pemeriksa Keuangan Republik Indonesia. 2016. Ikhtisar Hasil Pemeriksaan Semester I 2014, Buku II Pemeriksaan Laporan Keuangan, September 2014. Jakarta: Penerbitan BPK-RI.

Badan Pemeriksa Keuangan Republik Indonesia. 2017. Ikhtisar Hasil Pemeriksaan Semester II 2016. Maret 2017. Jakarta: Penerbitan BPK-RI.

Bauwhede, H.V . 2001. What Factors Influence Financial Statement Quality? A Framework and Some Empirical Evidence. Prepared for The Euroconference on Financial Reporting and Regulatory Practices in Europe. Palermo, Italy, May 20-23, 2001.

BPK RI Siaran Pers BPK Provinsi Kalimantan Barat: 2017a).

Damanik, Doni . 2010. Pengaruh Pengetahuan tentang Proses Audit Internal, Intuisi, Pemahaman tentang SAP dan Pengetahuan tentang Pengelolaan Keuangan Daerah terhadap peran Inspektorat dalam reviu laporan keuangan (studi Kasus pada Pemerintah Kabupaten Serdang Bedagai).Tesis. Medan. Program Pascasarjana Universitas Sumatera Utara.
Gordon L.A \& K.J. Smith (1992). Postauditing Capital Expenditures and Firm Performance. Account Org Society. November, pp. 741-757. I Gusti Agung Rai. 2010. Audit Kinerja pada Sektor Publik. Jakarta : Selemba Empat.

Irmawati (2013) Pengaruh Faktorfaktor SPIP terhadap Kualitas Laporan Keuangan Pemerintah Kota Madya Banda Aceh. Jurnal Akuntansi. 3 (2).

Kesuma, I., Nadirsyah, \& Darwanis (2014) Pengaruh Kompetensi Sumber Daya Manusia, Peran Internal Auditor dan Aktivitas Pengendalian terhadap Nilai Informasi Pelaporan Keuangan Pemerintah Daerah (Studi pada Pemerintah Kabupaten Aceh Utara). Jurnal Akuntansi. 3 (1): 73-82.

Krishnan, J. 2005. Audit Committee Quality and Internal Control: An Empirical Analysis. The Accounting Review. 80 (2): 649675.

Mahmudi. 2007. Manajemen Kinerja Sektor Publik. Yogyakarta : UPP STIM YKPN.

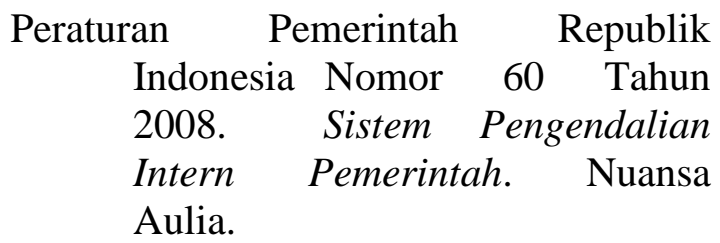

Peraturan Menteri Dalam Negeri Nomor 4 tahun 2008 tentang Pedoman Pelaksanaan Reviu atas Laporan Keuangan Daerah. 
Peraturan Pemerintah Nomor 71 Tahun 2010. Standar Akuntansi Pemerintahan. Fokusmedia.

Sekaran, Uma. 2006. Metode Penilitian untuk Bisnis, Buku 2, Edisi 4, Terjemahan oleh Kwan Men Yon. Salemba Empat: Jakarta.

Sekolah Tinggi Akuntansi Negara, 2007, Dasar-dasar Audit Intern Sektor Publik. Edisi I, Jakarta, Tim YPIA.

Shahwan, Yousef. 2008. Qualitative Characteristics of Financial Reporting: A Historical Perspective. Journal of Applied Accounting Research. 9 (3), pp. 192-202.

Simanjuntak, Binsar. 2012. Menyongsong Era Baru Akuntansi Pemerintahan di Indonesia.

http://www.ksap.org/sap/menyong song-era-baru-akuntansi-

pemerintahan-di-indonesia/. Diakses pada 24 April 2018.

Suhaili (2012) Penerapan Sistem Pengendalian Intern dan Peran Auditor Internal terhadap Kualitas Laporan Keuangan Pemerintah Daerah pada SKPD Kota Subussalam. Tesis. Banda Aceh. Program Pascasarjana Universitas Syiah Kuala.

Susilawati \& D.S. Riana. 2014. Standar Akuntansi Pemerintahan dan Sistem Pengendalian Intern Sebagai Anteseden Kualitas Laporan Keuangan Pemerintah Daerah. Jurnal STAR-Study \& Accounting Research. XI (1): ISSN: 1693-4482.
Syamsuar. 2013. Pengaruh Pemahaman Standar Akuntansi Pemerintahan dan Penerapan Sistem Pengendalian Intern terhadap Kualitas Laporan Keuangan Daerah pada SKPK Aceh Besar. Tesis. Banda Aceh. Program Pascasarjana Universitas Syiah Kuala.

Yunidar. 2011. Pengaruh Pengelolaan Aset, Penerapan Sistem Pengendalian Intern dan Peran Internal Audit terhadap Kualitas Laporan Keuangan Pemerintah Daerah. Tesis. Banda Aceh. Program Pascasarjana Universitas Syiah Kuala. 